\title{
Readings and Versions of Peter Pan in the Discursive Perspective
}

\author{
Valéria André dos Santos, $\mathrm{MsC}$ \\ State School “Rui Barbosa”, Glória D’Oeste, Mato Grosso, Brazil \\ E-mail: valeriasantos@unemat.br \\ Loiane Letícia dos Santos, MsC \\ Municipal Institute of Education of Catanduva - IMES, Catanduva, São Paulo, Brazil \\ E-mail: loiane.psicologia@gmail.com \\ Eliane Luiz dos Santos \\ State School “Rui Barbosa”, Glória D’Oeste, Mato Grosso, Brazil \\ E-mail: elianeluiz86@hotmail.com \\ Talessa L. F. Bromate \\ State School "Rui Barbosa”, Glória D’Oeste, Mato Grosso, Brazil \\ E-mail: talessa_leonarafb10@hotmail.com \\ Lorena Aline Santos Almeida \\ Doctor, Blumenau, Santa Catarina, Brazil \\ E-mail: lorena_aline@hotmail.com \\ Leonila Santos de Almeida Sasso \\ Independent Researcher, Mirassol, São Paulo, Brazil \\ E-mail: phdmonografia@gmail.com \\ Júlio César André, MD, PhD (Corresponding author) \\ Center for the Study and Development of Health Education - CEDES \\ Medical School of Medicine of São José do Rio Preto - FAMERP, Brazil
}

Received: March 13, 2020

doi:10.5296/jse.v10i2.16723
Accepted: April 7, 2020

Published: May 1, 2020

URL: https://doi.org/10.5296/jse.v10i2.16723 


\begin{abstract}
This article aims to present a practice of reading and writing in the discursive perspective, from versions of children's and young adult's literature and cinema, on reconstruction of stories. The theoretical basis supporting this reflection is Discourse Analysis (DA), anchored in the studies of Michel Pêcheux, in France, and Eni Puccinelli Orlandi, in Brazil. We started with the reading project Ler, contar e recontar (Reading, telling and retelling) in 2012, motivated by the concern about students presenting difficulties in writing and interpreting texts in all disciplines. The project's purpose is to perform DA on literary and cinematographic works in activities that lead to the establishment of similarities and differences among such materials. We provided visibility to the effects of meaning produced in the passage from the book to films and to drawings, considering the different processes of constitution, formulation and circulation of each significant materiality. By an approach involving reading the book, watching movies and examining drawings, added by discussions on effects of meaning of each and among them, it was possible to build the final product: a new version for the Peter Pan story, which was brought to the current days. Such story was presented on a festive night to the school community, showing the effects of authorship. It is worth remembering that it is not possible to invent a recipe. Our project is unique and even if someone wants to copy it, i.e., use the same methodology, the results will be different, as the subjects will be different, just like the production conditions, the time, the teacher, the activities etc. The unique production conditions of the conceived activities and the specific chosen class are responsible for the particular result of any proposal.
\end{abstract}

Keywords: Reading, Archive, Authorship, Writing, Significant materialities 


\section{Introduction}

Paraphrasing Orlandi (2010), since our beginning at school life as teachers, we need to problematize the ways of reading, showing the production conditions in which reading is inserted, leading the speaking subject or reader to reflect on the issues they produce, see and hear in different manifestations of language. "Reading is a practice that presupposes the subject's discursive memory's history and work whose the meanings are produced in relation to the conditions of production" (HASHIGUTI, 2009, p.28).

The classroom environment refers to heterogeneity, instability, controversy, litigation and difference. Such space must be flooded with texts of different significant materialities (FEDATTO, MACHADO, 2011, p.9) that circulate in different ways and can refer the student to a place populated by several voices, in which meanings are plural. There will be space for controversial discourse in which the discursive object is at stake in a situation of dispute and thus will be desired, written and spoken by students and teachers as subjects of language (ORLANDI, 1996).

This article discloses the experience provided by a search for professional development that made the classroom itself a laboratory for the development for skills. The study aimed to develop the practice of reading and writing in the discursive perspective, from versions of children's and young adult's literature for cinema and internet involving reconstruction of stories. The theoretical framework that supports this reflection is Discourse Analysis (DA), anchored in the studies of Michel Pêcheux, in France and Eni Puccinelli Orlandi in Brazil. Based on such sources, which are the main theoretical references of the article, follows the respective concepts and methodology.

The activity can be described as follows. First, there was a sequential reading of a book that included the four thematic axes chosen in a conversation circle among the students themselves. In a second moment, they read other versions and materialities (movies and drawings) with the intention of confronting various perspectives and realities. Finally, there was the elaboration of the final product: a play bringing a new version of Peter Pan, with a presentation based on the experiences of the students themselves and, consequently, different from other versions This form of effective verification of the reading practice reflected in writing has shown us that the ways of reading are by no means disconnected from writing practices. Therefore, the more the students read the better conditions they have to write.

\section{Steps of the project}

As the first step we conducted an informal conversation circle at the library of Escola Estadual Rui Barbosa (Rui Barbosa State School) in the city of Glória d'Oeste, state of Mato Grosso, Brazil, on October 19, 2015. In the event, the subject students reported what they like to do, how much they like the place where they live, what kind of movies they watch, which character in a story they would choose to stage, among other questions. We asked such questions to learn a little more about the profile of each subject student, which was a necessary condition for us to prepare our proposal. Next, we proposed the project, presented how it would be conducted and asked if they were willing to take part on the intervention process. We emphasized the need for them to be assertive, as the project would not prosper 
out of an emptiness of knowledge. At this point, we realized that it would be necessary that such knowledge could produce a meaning effect in language practices, depending on the production we would create. Four thematic axes emerged, with which the students identified a lot: magic, adventure, romance and comedy. However, it was then necessary to know more about each axis.

The second step consisted of the search the subject students conducted in different sources, such as the internet as well as encyclopedias filed in the library, regarding what constitutes these thematic axes. The third step was the intervention itself, which started with a welcoming dynamic and a speech on the importance of students for the project. We delivered an invitation to parents or guardians to attend a meeting, in which we presented the project, exposed the importance of their sons and daughters' participation. Then we obtained the proper authorization from the parents or guardians to take the subject students to the cinema. After delivering such invitations, we asked them to produce a written reflection on what they expected from this activity. And at the last meeting, we asked them to write a new report on whether or not these expectations were met. After all, it is a fact that "the school, as a place of reflection, is of fundamental importance to elaborate the experience of authorship regarding language" (ORLANDI, 2008, p. 21).

In the fourth step we showed the "backstage" of the book's production, i.e., how it came about, who the author was, how the play originated the book, how the characters emerged. We asked such questions to know what the subject student's previous knowledge was and what they would most like to know about it, for instance how to make a movie, if the plot is based on anything real, if they knew about how the title was created, what is Neverland, among other aspects.

The procedures involving data collection took place in the fifth step. Based on the theoretical framework the collected field material included: portrayals of the main characters for a better understanding of the plot; then, reading the chapters of the book, some in the classroom and others at home. Simultaneously, the subject students made notes and considerations in a field notebook about misunderstood or unknown points to be researched and worked on in classroom. Each read chapter was accompanied by a warm discussion about points and positions occupied by characters, as well as the resignification of these aspects by current view. On the occasion, the subject students also received a sketchbook to represent the scenes in the book that they imagined to be compared to the movie Peter Pan. It happened that most subject students were passionate about the art of drawing, and we started considering drawings as a significant materiality. The material consisted of an archive, the result of other gestures of interpretation, in view of the effects of polysemy, according to the reading history of each one, as the book and fiction are symbolic and historical objects that surround and constitute our daily life.

In the sixth step we presented other versions of books as suggestions to be read later to sharpen the interest for reading. It was also possible to bring up other meanings from the same text, according to who is the speaker, the position from which the discourse in made and the production conditions, thus achieving new meanings.

The seventh step consisted of watching the movie Peter Pan so that it was possible to appropriate its materiality and produce effects of meaning through interpretation gestures. In 
addition, it allowed the subject students to establish relationships between the languages of both the book and the movie, leading to the imaginary of both the reading and movie version. We also presented the other versions of the movie and the cartoon that appeared in that period. The last version released in 2015 shows the constitution of other meanings in the interpretation process and reinforced the idea that meanings may be different, according to the conditions of production and the position of the subject who produces it.

In the eighth step, we elaborated the final product, which consisted of a fragment of the play to be put together with the reading project presentation of the school. This play consisted of another ending to the Peter Pan story, bringing this fine story to the present day. The subject students elaborated the text in a reflexive way and were able to exercise a revealing criticism of the relativity of the meaning of the text and of the institutionalization of their text instead of another, thus building one meaning and setting aside as many other possible meanings that this story could have gained (GALLO, 1998, p.91).

Thus, there was space for writing, rewriting, revision, play rehearsals, posters making and printed and/or manuscript invitations, according to the conditions requested. Each group, based on the thematic axis of their preference, which was announced at the first conversation circle (magic, adventure, romance and comedy), made their own text, taking authorship into account authorship, for "the subject only becomes an author if what he/she produces is interpretable"(ORLANDI, 2008, p.70). That is our understanding of creating possibilities for resignification, as the subject students attribute new meanings to what has already been said, becoming authors in this process. And we dedicated the final step to the evaluation "in order to establish the point from which the subject of the experiment departed and has undergone some change after the process" (GALLO, 1998, p.116).

\section{Reading and writing from the discursive perspective}

The subject student assumed the position of author, who controls the meanings and tied an imaginary of beginning, middle and end, subverting order and taking responsibility for his discourse. We made these considerations to support the fundamental objective of the project, which was to work on reading and writing from a discursive perspective to develop the training of readers and authors. This happens through the constitution of a reading archive, based on children's and young adult's literature and cinema, in the (re)construction of stories, to enable the subject students to be authors, i.e., to carry out the "passage", from oral to written, when assuming their discourses, placing themselves in this process. As Gallo (1989, p.77) states, they place themselves in the "position" of those who write a text (by the moment when the subject students establish the relationship between the plot and the outcome) in the school space.

The subject students were able to make this "passage", from the moment they became authors of the play Era Peter Pan 2016, produced, reviewed and presented by them, from the readings of different versions. Portuguese language teaching has traditionally been rooted in practices anchored in instrumental teaching programs (grammars, textbooks, dictionaries, etc.). In addition, regulations in discursive training give cohesion to a form-subject and a conception of what language and knowing the language means (DI RENZO, 2008, p.13). The author states, however, that such practices are already saturated in the classroom and have 
become commonplace, so that the relationship of students with the Portuguese language does not allow the subject student to signify him/herself in it. Moreover, his/her relationship with reading occurs only in the description and contemplation of the language (p.13).

Such practices have been ingrained since the Middle Ages, when only clerics were allowed to read, speak and write on their own behalf. All the others performed repeated copying, transcription, extraction, classification, indexing and coding that constituted a reading of the subject's erasure behind the institution that employed them. We see this issue in close relation with the notion developed by Pêcheux regarding the social work division of reading (PÊCHEUX, 1982, p.51).

According to Sarian (2012), the naturalization process of intellectual work circumscribes, on the one hand, the university professor, the critic, the researcher, in the domain of knowledge, being granted to them "the right to produce original readings, and therefore, interpretations". Thus, they are authorized and legitimated to prepare textbooks. On the other hand, the subjects of schooling, teachers and students are enrolled in the domain of doing, to who is attributed "the subordinate task of preparing and sustaining 'documents, the so said interpretations' through anonymous gestures of literal treatment...” (PÊCHEUX, 2010, p.52).

The result of this practice keeps the student alienated, in a position of only receiving content, without participating as protagonist subjects in the institution's propositions. This is perhaps the reason why the discourse of preparing for the labor market is present, as it would also configure passive performance, just receiving commands (DALCICO, 2015). However, the school produces the imaginary of the place of formation of subjects of knowledge, who act in the transformation of society. For this reason, the school should provide the subject students with an active participation in all actions promoted within the scope of the teaching processes and political actions.

The school must consolidate in its pedagogical proposal curricular guidelines that offer and guarantee quality education based on legal parameters that guide its pedagogical practice. When implementing and following such guidelines, the school follows its path, respecting all existing specificities in the school space. Thus, it welcomes everyone, children, youth and adults with respect and adequate attention so that everyone has equal access and permanence at school. Thus, it forms critical citizens capable of acting in the transformation of society (Projeto Político Pedagógico, 2016, p.4).

Thus, the Rui Barbosa State School can be seen as a starting point, since it must guide its administrative pedagogical action through this project, a document of collective construction, politically committed to the Brazilian Curriculum Guidelines and the Orientações Curriculares para a Educação Básica de Mato Grosso (2010) [Curricular Guidelines for the Basic Education of the state Mato Grosso]. It reads: "it is committed to ensuring education of social quality, providing students with the development of skills and the construction of knowledge for the formation of human values in the achievement of full citizenship". As an example a practice already adopted by the school, there is the reading project: "Reading, telling and retelling", started in 2012, from a concern about the subject students who had difficulties in writing and interpreting texts in all subjects.

The school and, more precisely, the Portuguese language teachers, implemented a project 
four years ago that has as a stimulus a tour for those who read and review a certain number of pages, which gradually increases each year. The methodology consists, first, in reading different novels and, at a second moment, in producing a critical review to verify the read content. This form of effective verification of the reading practice reflected in writing has shown us that reading is not disconnected from the writing practices. Therefore, the more the students read, the better they write. Free choice reading has increasingly affected students and led to an improvement in writing production, understanding of the world and criticality, which is easily perceived in the summaries of the books produced, giving an effect of completeness to the objectives of the project.

This reading initiative has not yet involved all students and especially those who need it most: the ones with difficulties who had not yet adhered to the reading process. We sought some answers to this problem and even thought that perhaps the lack of interest in reading originated from the poor encouragement from teachers; or maybe we had given more importance to students already included in the process; or even, students might not yet have discovered themes and titles to which they could identify themselves.

After starting the readings from a discursive perspective, we understood that one of the major problems of this reading project was precisely the fact that only the content of this discursive materiality - the book - was considered. When analyzing the pages of a book, the Read, telling and retelling project reported only the main ideas of the text or the author's intention, through content questions related to its cohesion and coherence. However, they left aside questions that refer to another reading path, which distrusts everything that is obvious, such as: "What does this text not discuss?" (LAGAZZI, 2011, p.277) Such questions could be more pertinent and interesting to the understanding and interest of readers.

For DA, reading is understood as a production of meanings, as the subject reader, who deals with such meanings, represents the conjunction of two historicities: the history of the reader's readings and the history of readings of the text [...] that act dynamically in the constitution of 'his/her' specific reading, at a given moment. (ORLANDI, 2012b, p.150).

The set of readings made by the subject students partly configures the comprehensibility of each specific reader, and it is important to reflect on the possibility of the reading to be worked on. It can be part of the process of establishing meanings as we are always exposed to them and so are our students. But what differentiate one reader from another is the uniqueness and the way each of them positions his/herself before an object to be read and interpreted, registered through writing or other means of circulation. Moreover, the reading is crossed by the discursive memory of previous readings made by the subject or by other readers, as they produce effects resulting from the crossing of these contents. Therefore, what remains for us is that the way the teacher provides the conditions for the production of reading in the school context will enable students to read in a way that new meanings are produced.

Thus, there is a need to:

offer students elements to discuss and question the production conditions of the various discourses, so that the other historical meanings are also evidenced and they move and occupy another subject position. For DA, the displacement is in the possibility of producing effects of meaning different from those stabilized in their social 
group. (BOLOGNINI, 2009, p. 44).

By working with difference and within it, and in order to promote displacements in this way of reading, we aimed to provide conditions for students to appropriate different materialities to expand their reading repertoire. In addition, we tried to create the teacher-student/knowledge bond: "In the symbolic work, structured in incompleteness and contradiction, images, words, gestures, sounds and music compose drift possibilities that let us see the difference in their potential of surfacing the political in the social". (LAGAZZI, 2012, p.137).

According to DA, reading is concerned with meaning, but not the literal one, which is exclusive to the teacher or the author. From this perspective, it is not possible to silence other possibilities of interpretation and thus, the teacher can modify the conditions of production of student's reading: on the one hand, allowing him to build his reading history; on the other, establishing, when necessary, intertextual relations and rescuing the history of the text's meanings. (ORLANDI, 2015, p.44). Therefore, we believe it is necessary to form a reading file so that in this activity, "students begin to put themselves in the condition of authors assuming, before the school institution and outside it, a social role in the relationship with language" (ORLANDI, 2012b, p.106). To teach reading it is necessary to allow the reader to work with what he does not know. Reading can be precisely thought precisely as the construction of this relationship between discourse and text and this is where the teacher can provide the learning reader with such elements. (ORLANDI, 2012a, p.70).

To make this process happen, we started developing integrated practices of reading and writing of children's and young adult's literature and cinema, more specifically, Peter Pan's book and its movie version. By using such materials, we aimed to ressignify reading and writing meanings at school. As this project is inserted in the discursive perspective, we developed a work in which we authorized the circulation of different meanings, taking into account the historicity and production conditions these works were carried out. Thus, we conducted the activity according to the theoretical bases of DA, considering the specificities, history of reading and particularities of the subject-reader. It was possible to create a space in which historical repetition took place based on what the subject students already knew to elaborate other forms of effective knowledge in their conditions based on clippings from certain areas of the interdiscourse. Such areas allow to recognize, according to Hashiguti (2009, p.23), "the playful discourse in which interlocutors are exposed to the referent, with the circulation of meanings, i.e., the open polysemy" It is in this polysemy that the subject positions teacher and student are played. Misconceptions are the only certainty and the best. Many meanings are possible in this relationship. They are materializations of history constitution. (FEDATTO; MACHADO, 2011, p.14-15). The realization of an analysis including literary and cinematographic work, in a way that students can confront them through questions about the relations of similarities between the history of both the book and the movie: how do the changes happen, why they occur, and what effects of meaning were produced in the passage from the book to the movie. Browsing through the classics is not just reading books. The cinema has brought us good movies inspired by them, in more or less faithful versions, but that should not be forgotten as a possibility of contact with such 
contents. (MACHADO, 2002, p. 65).

The development of the activities took place in one meeting per week and lasted four hours during the first semester of 2016. In those meetings, we showed that reading a book is different from watching a movie, even if both deal with the same theme characters. It is necessary to show students that a cinematographic adaptation is not restricted to a simple judgment of value (which one is the best), "but that it emerged as a way of legitimizing cinema before an ascending bourgeoisie". (DE CONTI; MENSATO, 2011, p.16).

There are differences between students who live in the urban area and those who live in the countryside, who are seen as "hillbillies" and "without culture". Nevertheless, it was possible to observe that, among the school's readers, half are from rural area and the other half is from the urban area. As for discipline and interest, students from rural areas stand out more, eagerly seek education as a way to improve their lives, take higher education and return as members of the school's staff.

The teacher's tasks needs to be nurtured by a theory; this relationship is built as the teacher reads, is challenged, looks at his/her practice, evaluates, establishes relationships, exchanges experiences with colleagues and recognizes himself as capable of changes: The teacher can modify the production conditions of the students' reading, by both enabling them to build their reading history and establishing, when necessary, intertextual relations and rescuing the history of the text's meanings. (ORLANDI, 2015, p.44).

\section{Conclusion}

We can understand DA as a "theory of interpretation" that seeks, from its origin, to understand "how a text means", reflecting on how they are constituted, their production conditions and how the effects of meaning are produced, becoming fundamental in such transformation process. In this theory, "it is considered that reading is produced and sought to determine the process and conditions of such production" (ORLANDI, 1998, p.38). Such conditions need to consider subjects (author and reader), ideology, different types of discourse, and distinction between paraphrasic and polysemic reading. In addition, they install new meanings in the classroom, displacing the student from the mere recipient of content and meanings already legitimized and signaling the possibility of expression, questions and doubts.

Before getting to know the theory, we believed that reading should always be in verbal language; but after DA studies, we also discovered the importance of visual and sound languages, with the aim of exploring the details of a scene and verifying how symbolic objects produce effects of meaning (ORLANDI, 2015). And that was how we reached the result: in a succession of readings of the book, movies and drawings, added by discussions about the effects of meaning of each and all of them. By getting everything together it was possible to build the final product: a new version for the Peter Pan story, bringing the story to the current days, which was presented on a festive night for the school community, showing the effects of authorship. "Therefore, author is the subject who, having mastered certain discursive mechanisms, represents, through language, this role in the social order he is 
inserted" (ORLANDI, 2012b, p.105).

It is worth remembering that it is not possible to invent a recipe. Our project is unique and even if someone wants to copy it, i.e., use the same methodology, the results will be different, as the subjects will be different, just like the production conditions, the time, the teacher, the activities etc. The unique production conditions of the conceived activities and the specific chosen class are responsible for the particular result of any proposal.

\section{References}

Bolognini, C. Z. (Ed.). (2007). Cinema at school. Campinas: Mercado das Letras.

Bolognini, C. Z., \& Pfeifer, C. L. S. (Orgs.). (2009). Language practices at school. Campinas: Mercado das Letras.

Calvino, I. (2006). Fairy tales, when the hat changes color. In: L. M. S. Romão, \& S. R. Pacífico, Once upon a time another story: reading and interpreting in the classroom (pp. 60-61). São Paulo: DCL.

Dalcico, E. C. (2015). New gestures of interpretation: the challenge of "teaching" how to read (Doctoral dissertation, Universidade do Estado de Mato Grosso, Mato Grosso, Brazil). Available

http://portal.unemat.br/media/files/profLetrasCACERES/ELIANE\%20DALCICO.pdf (February 03, 2020).

De Conti, D. F., \& Mensato, J. (2011). From warehouses to auditoriums: the role of literature in the consolidation of cinema. In C. Z. Bolognini (Org.), Speech and teaching: reading in cinema (pp. 9-17). Campinas, SP: Mercado das Letras.

Di Renzo, A. M. (2008). School and the formulation of Linguistic Policies. Revista Letras da Universidade de Brasília, 1(2), 5-15. Available http://www.unemat.br/caceres/letras/docs/docente/ana_di_renzo_escola_formulacao_politicas .pdf (February 03, 2020).

Escola Estadual Rui Barbosa (2016). Pedagogical Political Project (PPP). Monte Castelo D'Oeste, MT: EE Rui Barsosa.

Fedatto, C. P., \& Bezerra, R. (2011). Land of Never and Truth - the history of the senses. In C. Z. Bolognini (Org.), Speech and teaching: reading in cinema (pp. 31-38). Campinas, SP: Mercado de Letras.

Fedatto, C. P., \& Machado, C. P. (2007). The wall, courtyard and coral or the senses in/of the teacher. In C. Z. Bolognini (Org.), Speech and teaching: cinema at school (pp. 9-16). Campinas, SP: Mercado de Letras.

Gallo, S. L. (1990). Teaching of written language $x$ teaching of written speech (Doctoral dissertation, Instituto de Estudos da Linguagem, Universidade Estadual de Campinas, Campinas, SP, Brazil). Available http://repositorio.unicamp.br/jspui/bitstream/REPOSIP/270686/1/Gallo_SolangeLeda_M.pdf 
(February 03, 2020).

Hashiguti, S. T. (2009). Nas teias da leitura. In: C. Z. Bolognini, C. Pfeifer, C., \& S. Lagazzi (Orgs.), Language practices at school (pp. 19-38). Campinas: Mercado das letras.

Lagazzi-Rodrigues, S. (2009). Significant clipping in memory. In F. Indursky, M. C. L. Ferreira, \& S. Mittmann (Orgs.). The discourse in contemporaneity. Materialities and borders (pp. 67-68). São Carlos: Clara Luz. Available https://issuu.com/prazeremler/docs/contemporaneidade (April 07, 2020)

Lagazzi-Rodrigues, S. (2011). Discourse analysis: significant materiality in history. In A. Di Renzo, A. L. A. Rodrigues, \& T. Pitombro (Orgs.). Language, history and memory: moving speeches (pp. 275-290). Campinas: Pontes.

Lagazzi-Rodrigues, S. (2012). The discourse in different territories: the red among all colors. In S. O. Maluf, V. Silva, E. Almeida, \& L. S. J. Bisinoto (Orgs). Speech, subject and memory (pp. 133-146). Campinas: Pontes.

Machado, A. M. (2002). How and why to read universal classics from an early age. Rio de Janeiro: Objetiva.

Orlandi, E. P. (1993). Neither writer nor subject: only author. In E. P. Orlandi, Speech and Reading (pp. 183-194). São Paulo: Cortez.

Orlandi, E. P. (2004). City of the senses. Campinas: Pontes.

Orlandi, E. P. (2009). Language and its functioning: the forms of discourse. (5th ed.). Campinas, SP: Pontes.

Orlandi, E. P. (2012a). Speech and text: formulation and circulation of the senses. (3rd ed). Campinas, SP: Pontes.

Orlandi, E. P. (2012b). Speech and Reading. (9th ed.). São Paulo: Cortez.

Orlandi, E. P. (2012c). Interpretation, authorship, reading and effects of symbolic work. Campinas: Pontes.

Orlandi, E. P. (2013). Language and linguistic knowledge: for a history of ideas in Brazil. (2nd ed). São Paulo: Cortez.

Orlandi, E. P. (2015). Discourse analysis: principles and procedures. (9th ed.). Campinas, SP: Pontes.

Orlandi, E. P., \& Lagazzi-Rodrigues, S. (Orgs.). (2015). Introduction to language sciences: discourse and textuality. (3rd ed). Campinas: Pontes.

Pêcheux, M. (2006). The discourse: structure or event. (4th ed.). Campinas: Pontes.

Pêcheux, M. (1994). Read the file today. In E. P. Orlandi (Org.), Reading gestures: from the story in the speech (pp. 49-59). Campinas: Editora da Unicamp. Available https://edisciplinas.usp.br/pluginfile.php/4931448/mod_label/intro/PECHEUX_LerOArquivo Hoje.pdf (February 03, 2020).

Pêcheux, M. (1995). Semantics and discourse: a critique of the affirmation of the obvious. (2nd ed.) Campinas: Edunicamp, Unicamp. 
Sairan, M. C. (2012). The injunction to the new and the repetition of the old: a discursive view of the Program Um Computador por Aluno (PROUCA) (Doctoral dissertation, Instituto de Estudos da Linguagem, Universidade Estadual de Campinas, Campinas, SP, Brazil). Available

http://repositorio.unicamp.br/jspui/bitstream/REPOSIP/270532/1/Sarian_MaristelaCury_D.p df (February 03, 2020).

Secretaria de Estado de Educação de Mato Grosso. (2010). Curriculum guidelines: conceptions for basic education. Cuiabá, MT: SEDUC/MT. Available http://cos.seduc.mt.gov.br/upload/permanente/Arquivo/LIVRO\%20CONCEPCOES\%20com \%20ficha\%20catalografica79156916090010.pdf (February 03, 2020) 